\title{
Why all blood donations should be tested for hepatitis E virus (HEV)
}

\author{
Joachim Denner ${ }^{1 *}\left(\mathbb{D}\right.$, Sven Pischke ${ }^{2}$, Eike Steinmann ${ }^{3}$, Johannes Blümel ${ }^{4}$ and Dieter Glebe ${ }^{5}$
}

\begin{abstract}
Background: Hepatitis $E$ is a liver disease caused by a small RNA virus known as hepatitis E virus (HEV). Four major genotypes infect humans, of which genotype 1 and 2 (HEV-1, HEV-2) are endemic mainly in Asia and responsible for waterborne epidemics. HEV-3 and HEV-4 are widely distributed in pigs and can be transmitted to humans mainly by undercooked meat, and contact with pigs. HEV-3 is the main genotype in industrialised countries with moderate climate conditions and object of this debate.

Main text: Whereas an HEV-3 infection in healthy humans is mostly asymptomatic, HEV-3 can induce chronic infection in immunocompromised individuals and acute-on-chronic liver failure (ACLF) in patients with underlying liver diseases. The number of reported cases of HEV-infections in industrialised nations increased significantly in the last years. Since HEV-3 has been transmitted by blood transfusion to other humans, testing of blood donors has been introduced or introduction is being discussed in some industrialised countries. In this article we summarise the arguments in favour of testing all blood donations for HEV-3.

Conclusion: The number of HEV infection in the population and the possibility of HEV transmission by blood transfusion are increasing. Transmission by blood transfusion can be dangerous for the recipients considering their immunosuppressive status, underlying disease or other circumstances requiring blood transfusion. This argues in favour of testing all blood donations for HEV-3 to prevent transmission.
\end{abstract}

Keywords: Hepatitis E virus, Blood donations, Blood transfusion, Safety, Blood testing

\section{Background}

Blood transfusion is a lifesaving procedure to replace blood cells or plasma lost through severe bleeding, e.g., during surgery when blood loss occurs. It is also used in anemic patients as an essential part of treatment. In 2014, nearly 3.8 million units of packed red blood cells, 485,000 thrombocyte or platelet concentrates, and 796,000 units plasma were used for transfusions in Germany [1].

In order to avoid transmission of microorganisms from the donor to the recipient, strong regulations are in force. All donations in Germany must be tested for antibodies against human immunodeficiency virus 1 (HIV-1) and HIV-2, against human hepatitis $\mathrm{C}$ virus (HCV), against human hepatitis $\mathrm{B}$ core antigen $(\mathrm{HBcAg})$, as well as for human hepatitis B surface antigen (HBsAg) and for the genomes of $\mathrm{HCV}$ and $\mathrm{HIV}$ using nucleic acid testing (NAT) [2]. Thus, transfusion-associated transmissions of

\footnotetext{
* Correspondence: DennerJ@rki.de

${ }^{1}$ Robert Koch Institute, Nordufer 20, 13353 Berlin, Germany

Full list of author information is available at the end of the article these viruses are rare [3]. Also transmission of other viruses including West Nile virus (WNV), human $\mathrm{T}$ cell lymphotropic virus (HTLV), rabies virus as well as of parasites (mainly malaria) and bacteria has been reported with a very low risk [3].

In Germany, testing of all blood donations for HEV is in preparation to be introduced. A nationwide HEV RNA universal screening of blood donations has already been introduced in Ireland, the UK, Japan and the Netherlands. In Switzerland, nucleic acid screening of all blood products for HEV started in November 2018 [4]. Blood authorities in Greece, Portugal, Italy, France and Spain are evaluating the situation [5]. Recently, the responsible German authority, the Paul-Ehrlich-Institut, recommended testing all blood donations for HEV. Here, we discuss the relative risk, posed by HEV transmission via transfusion and summarise the major arguments recommending the testing of all blood donations for HEV.

(C) The Author(s). 2019 Open Access This article is distributed under the terms of the Creative Commons Attribution 4.0 International License (http://creativecommons.org/licenses/by/4.0/), which permits unrestricted use, distribution, and reproduction in any medium, provided you give appropriate credit to the original author(s) and the source, provide a link to the Creative Commons license, and indicate if changes were made. The Creative Commons Public Domain Dedication waiver (http://creativecommons.org/publicdomain/zero/1.0/) applies to the data made available in this article, unless otherwise stated. 


\section{HEV - biology and prevalence}

$\mathrm{HEV}$ is a single-stranded, positive-sense RNA virus classified in the family Hepeviridae [6]. The HEV particles present in feces and bile are nonenveloped, while those in circulating blood and culture supernatants are covered with a cellular membrane, similar to enveloped viruses and called quasi-enveloped [7]. There are eight genotypes of HEV: HEV-1 and HEV-2 are primarily human viruses, whereas HEV-3 and HEV-4 were found in pigs, humans and other animals. HEV-5 and HEV-6 were described only in wild boars in Japan, HEV-7 was found in a dromedary camels and HEV-8 in Bactrian camels [8]. HEV-1 and HEV-2 are endemic in regions in Asia and Africa, the major source of infection is contaminated water (for review see [6]). HEV-3 and HEV-4 are zoonotic viruses transmitted to humans mainly by direct contact with pigs or eating undercooked pork. Seroprevalences of HEV-3 in domestic pigs were estimated between 5 and 100\% [9]. The detection of viral RNA and virus-specific antibodies depends significantly on the analysed pig material, the age of the animals and the detection methods (PCR, real-time PCR, ELISA and Western blot analysis) [10-12].

Usually pigs are infected at an early age after the loss of the maternal antibodies, a peak of viral excretion in pig fecal samples is detected between week three and eight after weaning, the excretion decreases with the appearance of antibodies. Detection of viral RNA in serum samples is less frequent than in liver and fecal samples [9]. HEV-7 was also found in a liver transplanted patient regularly consuming camel meat and milk [13]. HEV infections have little impact on animal health, the animals have no obvious symptoms, however co-infection with other viruses may increase the amount and the duration of HEV secretion or induce even fatal diseases [14].

\section{Transmission of HEV-3 in pigs and humans}

Whereas oral-fecal transmission is the major way of HEV transmission in pigs, transmission via the placenta was also detected [15]. Contact with pigs and the consumption of undercooked pork meat is the main way of transmission of HEV-3 to humans. HEV was also found in wild boars [16-18] and screening of wild boar hunters, forest workers and pet pig holders gave good evidence that HEV is transmitted by contact with pigs and wild boars [19, 20]. Many reports describe the detection of HEV RNA in pig liver, meat and meat products intended for human consumption (for review see [6]). In addition, HEV infections have been reported after consumption of shellfish and vegetables, obviously due to a contamination with pig manure [21-23]. Transmission has also been reported after consumption of wild boar meat [24].
The seroprevalence of HEV-3 in the general population of Western countries has been shown to differ, partially due to the use of different assays [10, 11, 25].

The HEV seroprevalence and viremia in blood donors was also shown to differ in Western countries (Table 1) [26-40]. In the Southwest of France even 52\% positive donors were found, here mainly due to the consumption of undercooked figatellu liver sausages [27]. Studies in Germany showed an anti-HEV IgG prevalence of $6.8 \%$ [41], the rate of HEV-positive donations was 1:4525 [42] and hepatitis E viraemia was found at a relatively high rate of $0.12 \%$ among blood donors in 2018 [42]. In comparison with Europe and the United States, the seroprevalence was lower in Latin America [43, 44]. In Switzerland on average $29.4 \%$ of blood samples were positive, the seroprevalence increased with age $(30.7 \%$ of males and $34.2 \%$ of women over 60 years old) [4]. An increase of seropositive donors with age was also observed in France [27].

Due to the high prevalence in blood donors, transmission of HEV by blood transfusion has been observed [4, 26, 32, 33, 44-47], but not all patients receiving HEVpositive blood got infected [33, 44, 46]. The infectivity of $\mathrm{HEV}$-contaminated components for transfusion was in one study 50\% [48] and seems to depend upon the virus load $[33,46]$. HEV transmission depends not only on the virus load, but also on the blood component given and on the presence of antibodies in the preparation [33]. Overall, donations containing antibody were less likely to transmit. HEV transmission was also associated with organ transplantation, but only in single cases [4951]. The prevalence of persistent HEV infection in patients with solid organ transplantation in Western Europe varies between 0.7 and 3.2\% [52]. The different observed incidences strongly depend on the respective antibody test applied in the respective study.

Table 1 HEV seroprevalence and viremia in blood donors in Western countries

\begin{tabular}{lllll}
\hline Country & $\begin{array}{l}\text { HEV IgG } \\
\text { positive (\%) }\end{array}$ & $\begin{array}{l}\text { RNA } \\
\text { positive }\end{array}$ & Reference & $\begin{array}{l}\text { Year of } \\
\text { publication }\end{array}$ \\
\hline Germany & 29.5 & $1: 1200$ & {$[26]$} & 2012 \\
France & 22.4 & $1: 2218$ & {$[27,28]$} & 2014,2016 \\
& & $1: 744$ & {$[29]$} & 2017 \\
The Netherlands & 27.0 & $1: 2671$ & {$[30]$} & 2012 \\
& & 1.600 & {$[31]$} & 2015 \\
England & 12.0 & $1: 2848$ & {$[32]$} & 2011 \\
& & $1: 7000$ & {$[33]$} & 2012 \\
Scotland & 4.7 & $1: 14520$ & {$[34]$} & 2013 \\
Denmark & & $1: 2330$ & {$[35]$} & 2016 \\
Spain & 19.9 & $1: 3333$ & {$[36]$} & 2015 \\
\hline
\end{tabular}


Most infections of immunocompetent humans with HEV-3 are asymptomatic, in rare cases a mild anicteric illness and a moderate hepatitis were reported. In some cases an acute hepatitis by red blood cell transfusion was described in immunocompetent subjects [53]. In a patient with thrombotic thrombocytopenic purpura (TTP), an acute HEV infection by cryosupernatant plasma triggered exacerbation of the TTP [54]. HEV infection becomes chronic in patients who are immunosuppressed (HIV-infection, transplantation, chemotherapy, rheumatic diseases), however chronic HEV infection was also observed in an immunocompetent patient with a history of systemic lupus erythematosus [55]. Neurological manifestations caused by HEV infections have been reported, but they are still not well analysed [56]. In patients with underlying liver disease, a severe hepatitis occurs [19]. HEV may be an immunosuppressive virus. There is evidence in a pig model of chronic HEV infection that HEV actively suppressed cellular immune responses [57] and increased levels of the immunosuppressive IL-10 have been found in HEV-infected individuals [58].

HEV infected individuals can be treated with the antiviral ribavirin and for prophylaxis, a human vaccine, at least against HEV-1, was developed. However the efficacy against HEV-3 has still not been specifically tested and this vaccine has no approval outside of China $[59,60]$. There is evidence that the number of reported HEV-3 infections increases not only due to greater awareness and better testing, but also due to a real increase in infection rates $[31,36,61]$. However, in Switzerland the number of human infections declined [40]. Within the specified region of the Swiss Bern canton, overall prevalence has declined over two decades from $30.3 \%$ in $1997 / 98$ to $27.0 \%$ in 2006 and $22.3 \%$ in $2015 / 6$ [4].

\section{The need of testing of all blood donations}

As mentioned above, several reports have described transfusion-transmitted HEV infections [4, 26, 32, 33, 42, $44,46,47]$. In one case, HEV transmission was associated with fatal hepatitis in a Japanese cancer patient [62]. However, it is obvious that the risk of infection through meat consumption is much higher compared with transmission by blood transfusion. Screening blood donations will not prevent most cases of HEV transmission, but it will significantly reduce the risk for the transfusion recipients, which are either immunosuppressed and/or suffering from different diseases. In addition, there is a great difference between a person who takes up the virus orally and a person who gets infected intravenously. In the case of oral uptake there may be some protection by the acidic environment of the stomach and the mucosal barrier in the gut. Immunocompromised patients need often multiple transfusions, which increases the risk from transmission [46].
HEV was detected in 1 of 815 blood donations in Germany [45] and is 100 times more prevalent compared with HIV, HCV and HBV combined. Risk estimations considering both, the HEV prevalence and clinical risk for immunocompromised patients $[63,64]$ led to introduction of blood screening for HEV in the Netherlands and Germany. Analysing the cost-effectiveness of the screening of blood donations for HEV in the Netherlands, the authors came to the conclusion that preventing HEV transmission by screening of blood donations appears not excessively expensive compared to other blood screening measures [63]. However, since only a small number of HEV infections are due to blood transfusions, the overall impact on HEV disease burden will be small [63]. To reduce de novo infections in general, several strategies have been proposed [65].

It may be assumed that it may be sufficient to test only the blood donations for people at risk, e.g., immunosuppressed organ transplant recipients and recipients of haematopoietic stem cells. Such a limited testing seemed cost effective while protecting patients at major risk. However, there are several arguments for universal screening of all blood donations. First, the category "people at risk" is difficult to define due to individual variability. Cancer patients under chemotherapy, HIV infected individuals, and patients with rheumatoid arthritis and other rheumatic diseases under immunosuppressive treatment should also be included. The fatal outcome of a transfusiontransmitted infection of a cancer patient in Japan [62] underlines that the risk-group should not be limited to transplant patients alone. Second, even immunocompetent patients may suffer from acute HEV-infection or induced complications under circumstances requiring blood or plasma transfusion $[54,55,66,67]$. Third, the handling of two separate types of blood donations would increase logistical cost and may even lead to product losses due to the stockpiling of tested and non-tested donations. For example, in the case more tested material is required, stored non-tested material will not be used and may expire and vice versa. Fourth, it may be very difficult or even impossible for a physician to assign a patient to an HEV risk in an emergency requiring transfusion.

\section{Conclusion}

HEV-contaminated food is the main source of HEV transmission to humans in Europe and other industrialised countries with moderate climate conditions. However, transmission by blood transfusion can be dangerous for the recipients considering their immunosuppressive status, underlying disease or other circumstances requiring blood transfusion. Several of the arguments discussed above in detail argue in favour of testing all blood donations for HEV-3 to prevent transmission. Based on these arguments, blood donor testing has been introduced in several industrialised countries, including recently Germany. 


\section{Abbreviations}

ACLF: Acute-on-chronic liver failure; HBcAg: Hepatitis B core antigen; HBsAg: Hepatitis B surface antigen; HCV: Hepatitis C virus; HEV: Hepatitis E virus; HIV: Human immunodeficiency virus; HTLV: Human T cell Iymphotropic virus; NAT: Nucleic acid testing; WNV: West Nile virus

\section{Acknowledgments}

The authors would like to thank Prof. H. Hengel (GfV) and Prof. H. Fickenscher (DW) for critical review of the manuscript. All authors are members of the commission "Virus safety in transfusion and transplantation" of the Society for Virology in Germany (GF) and the German Association for the Control of Virus Diseases (DW)

\section{Authors' contributions}

JD proposed and planned the article, all authors (JD, SP, ES, JB, DG) contributed equally, the authors read and approved the final manuscript.

\section{Funding}

None.

\section{Availability of data and materials Not applicable.}

\section{Ethics approval and consent to participate}

Not applicable.

\section{Consent for publication}

Not applicable.

\section{Competing interests}

The authors declare that they have no competing interests.

\begin{abstract}
Author details
${ }^{1}$ Robert Koch Institute, Nordufer 20, 13353 Berlin, Germany. ${ }^{2} 1$. Medizinische Klinik, Universitätsklinikum Hamburg-Eppendorf, Martinistrasse 52, 20246 Hamburg, Germany. ${ }^{3}$ Ruhr-Universität Bochum, Universitätsstraße 150, 44801 Bochum, Germany. ${ }^{4}$ Paul-Ehrlich-Institut, Paul-Ehrlich-Straße 51-59, 63225 Langen, Germany. ${ }^{5}$ Institute of Medical Virology, National Reference Centre for Hepatitis B and D Viruses, German Center for Infection Research (DZIF), Schubertstr. 81, Justus-Liebig-Universität Giessen, 35392 Giessen, Germany.
\end{abstract}

Received: 7 March 2019 Accepted: 13 June 2019

Published online: 20 June 2019

\section{References}

1. Takei T, Amin NA, Schmid G, Dhingra-Kumar N, Rugg D. Progress in global blood safety for HIV. J Acquir Immune Defic Syndr. 2009; 52(Suppl 2):S127-31.

2. Richtlinie zur Gewinnung von Blut und Blutbestandteilen und zur Anwendung von Blutprodukten (Richtlinie Hämotherapie). Bundesärztekammer, (guideline for the production of blood and blood components and the use of blood products (guideline for hemotherapy). German Medical Association), 2017. https://www.bundesaerztekammer.de/ fileadmin/user_upload/downloads/pdf-Ordner/MuE/Richtlinie_ Haemotherapie 2017.pdf. Accessed 17 June 2019.

3. Perkin HA, Busch P. Transfusion-associated infections: 50 years of relentless challenges and remarkable progress. Transfusion. 2010;50:2080-99.

4. Niederhauser C, Widmer N, Hotz M, Tinguely C, Fontana S, Allemann G, Borri M, Infanti L, Sarraj A, Sigle J, Stalder M, Thierbach J, Waldvogel S, Wiengand T, Züger M, Gowland P. Current hepatitis E virus seroprevalence in Swiss blood donors and apparent decline from 1997 to 2016. Euro Surveill. 2018;23(35).

5. Domanović D, Tedder R, Blümel J, Zaaijer H, Gallian P, Niederhauser C, Sauleda Oliveras S, O'Riordan J, Boland F, Harritshøj L, Nascimento MSJ, Ciccaglione AR, Politis C, Adlhoch C, Flan B, Oualikene-Gonin W, Rautmann G, Strengers P, Hewitt P. Hepatitis E and blood donation safety in selected European countries: a shift to screening? Euro Surveill. 2017;22(16).

6. Johne R, Dremsek P, Reetz J, Heckel G, Hess M, Ulrich RG. Hepeviridae: an expanding family of vertebrate viruses. Infect Genet Evol. 2014;27:212-29.

7. Nagashima S, Takahashi M, Kobayashi T, Tanggis NT, Nishiyama T, Primadharsini PP, Okamoto $\mathrm{H}$. Characterization of the quasi-enveloped hepatitis E virus particles released by the cellular Exosomal pathway. J Virol. 2017;(22):91.

8. Woo PC, Lau SK, Teng JL, Cao KY, Wernery U, Schountz T, Chiu TH, Tsang AK, Wong PC, Wong EY, Yuen KY. New hepatitis E virus genotype in Bactrian camels, Xinjiang, China, 2013. Emerg Infect Dis. 2016;22(12):2219-21.

9. Pavio N, Doceul V, Bagdassarian E, Johne R. Recent knowledge on hepatitis E virus in Suidae reservoirs and transmission routes to human. Vet Res. 2017; 48(1):78.

10. Bendall R, Ellis V, ljaz S, Ali R, Dalton $H$. A comparison of two commercially available anti-HEV IgG kits and a re-evaluation of anti-HEV IgG seroprevalence data in developed countries. J Med Virol. 2010;82(5):799-805.

11. Al-Absi ES, Al-Sadeq DW, Younis MH, Yassine HM, Abdalla OM, Mesleh AG, Hadwan TA, Amimo JO, Thalib L, Nasrallah GK. Performance evaluation of five commercial assays in assessing seroprevalence of HEV antibodies among blood donors. J Med Microbiol. 2018;67(9):1302-9.

12. Dremsek $P$, Joel $S$, Baechlein $C$, Pavio N, Schielke A, Ziller M, Dürrwald $R$, Renner C, Groschup MH, Johne R, Krumbholz A, Ulrich RG. Hepatitis E virus seroprevalence of domestic pigs in Germany determined by a novel inhouse and two reference ELISAs. J Virol Methods. 2013;190:11-6.

13. Lee GH, Tan BH, Teo EC, Lim SG, Dan YY, Wee A, Aw PP, Zhu Y, Hibberd ML, Tan CK, Purdy MA, Teo CG. Chronic infection with camelid hepatitis E virus in a liver transplant recipient who regularly consumes camel meat and Milk. Gastroenterology. 2016;150(2):355-7 e3.

14. Yang Y, Shi R, She R, Mao J, Zhao Y, Du F, Liu C, Liu J, Cheng M, Zhu R, Li W, Wang $X$, Soomro MH. Fatal disease associated with swine hepatitis $E$ virus and porcine circovirus 2 co-infection in four weaned pigs in China. BMC Vet Res. 2015;11:77.

15. Morozov VA, Morozov AV, Rotem A, Barkai U, Bornstein S, Denner J. Extended microbiological characterization of Göttingen Minipigs in the context of xenotransplantation: detection and vertical transmission of hepatitis E virus. PLoS One. 2015;10(10):e0139893.

16. Schielke A, Sachs K, Lierz M, Appel B, Jansen A, Johne R. Detection of hepatitis $E$ virus in wild boars of rural and urban regions in Germany and whole genome characterization of an endemic strain. Virol J. 2009;6:58.

17. Widén F, Sundqvist L, Matyi-Toth A, Metreveli G, Belák S, Hallgren G, Norder $H$. Molecular epidemiology of hepatitis $E$ virus in humans, pigs and wild boars in Sweden. Epidemiol Infect. 2011;139(3):361-71.

18. Krumbholz A, Mohn U, Lange J, Motz M, Wenzel JJ, Jilg W, Walther M, Straube E, Wutzler $P$, Zell R. Prevalence of hepatitis E virus-specific antibodies in humans with occupational exposure to pigs. Med Microbiol Immunol. 2012;201:239-44.

19. Hartl J, Wehmeyer MH, Pischke S. Acute hepatitis E: two sides of the same coin. Viruses. 2016;8(11)

20. Sommerkorn FM, Schauer B, Schreiner T, Fickenscher H, Krumbholz A. Performance of hepatitis E virus (HEV)-antibody tests: a comparative analysis based on samples from individuals with direct contact to domestic pigs or wild boar in Germany. Med Microbiol Immunol 2017. 2017;206:277-86.

21. Grodzki M, Schaeffer J, Piquet JC, Le Saux JC, Chevé J, Ollivier J, Le Pendu J, Le Guyader FS. Bioaccumulation efficiency, tissue distribution, and environmental occurrence of hepatitis $E$ virus in bivalve shellfish from France. Appl Environ Microbiol. 2014;80(14):4269-76.

22. O'Hara Z, Crossan C, Craft J, Scobie L. First report of the presence of hepatitis E virus in Scottish-harvested shellfish purchased at retail level. Food Environ Virol. 2018;10(2):217-21.

23. Kokkinos P, Kozyra I, Lazic S, Bouwknegt M, Rutjes S, Willems K, Moloney R, de Roda Husman AM, Kaupke A, Legaki E, D'Agostino M, Cook N, Rzeżutka A, Petrovic T, Vantarakis A. Harmonised investigation of the occurrence of human enteric viruses in the leafy green vegetable supply chain in three European countries. Food Environ Virol. 2012;4(4):179-91.

24. Faber M, Askar M, Stark K. Case-control study on risk factors for acute hepatitis E in Germany, 2012 to 2014. Euro Surveill. 2018;23(19).

25. Wenzel JJ, Preiss J, Schemmerer M, Huber B, Jilg W. Test performance characteristics of anti-HEV lgG assays strongly influence hepatitis $\mathrm{E}$ seroprevalence estimates. J Infect Dis. 2013;207(3):497-500.

26. Vollmer T, Diekmann J, Johne R, Eberhardt M, Knabbe C, Dreier J. Novel approach for detection of hepatitis $\mathrm{E}$ virus infection in German blood donors. J Clin Microbiol. 2012;50(8):2708-13.

27. Mansuy JM, Gallian P, Dimeglio C, Saune K, Arnaud C, Pelletier B, Morel P, Legrand $D$, Tiberghien $P$, Izopet J. A nationwide survey of hepatitis $E$ viral infection in French blood donors. Hepatology. 2016;63(4):1145-54. 
28. Gallian $P$, Lhomme $S$, Piquet $Y$, Sauné $K$, Abravanel F, Assal A, Tiberghien $P$, Izopet J. Hepatitis E virus infections in blood donors. France Emerg Infect Dis. 2014;20(11):1914-7.

29. Gallian P, Couchouron A, Dupont I, Fabra C, Piquet Y, Djoudi R, Assal A, Tiberghien P. Comparison of hepatitis E virus nucleic acid test screening platforms and RNA prevalence in French blood donors. Transfusion. 2017; 57(1):223-4

30. Slot E, Hogema BM, Riezebos-Brilman A, Kok TM, Molier M, Zaaijer HL. Silent hepatitis E virus infection in Dutch blood donors, 2011 to 2012. Euro Surveill. 2013;18(31).

31. Zaaijer HL. No artefact, hepatitis E is emerging. Hepatology. 2015;62:654.

32. Beale MA, Tettmar K, Szypulska R, Tedder RS. ljaz S. is there evidence of recent hepatitis $E$ virus infection in English and north welsh blood donors? Vox Sang. 2011;100(3):340-2.

33. Hewitt PE, ljaz S, Brailsford SR, Brett R, Dicks S, Haywood B, Kennedy IT, Kitchen A, Patel P, Poh J, Russell K, Tettmar Kl, Tossell J, Ushiro-Lumb I, Tedder RS. Hepatitis E virus in blood components: a prevalence and transmission study in Southeast England. Lancet. 2014;384(9956):1766-73.

34. Cleland A, Smith L, Crossan C, Blatchford O, Dalton HR, Scobie L, Petrik J. Hepatitis E virus in Scottish blood donors. Vox Sang. 2013;105(4):283-9.

35. Harritshøj LH, Holm DK, Saekmose SG, Jensen BA, Hogema BM, Fischer TK, Midgley SE, Krog JS, Erikstrup C, Ullum H. Low transfusion transmission of hepatitis E among 25,637 single-donation, nucleic acid-tested blood donors. Transfusion. 2016;56(9):2225-32.

36. Sauleda S, Ong E, Bes M, Janssen A, Cory R, Babizki M, Shin T, Lindquist A, Hoang A, Vang L, Piron M, Casamitjana N, Koppelman M, Danzig L, Linnen $J M$. Seroprevalence of hepatitis E virus (HEV) and detection of HEV RNA with a transcription-mediated amplification assay in blood donors from Catalonia (Spain). Transfusion. 2015;55(5):972-9.

37. Mansuy JM, Bendall R, Legrand-Abravanel F, Sauné K, Miédouge M, Ellis V, Rech H, Destruel F, Kamar N, Dalton HR, Izopet J. Hepatitis E virus antibodies in blood donors, France. Emerg Infect Dis. 2011;17(12):2309-12.

38. Hogema BM, Molier M, Slot E, Zaaijer HL. Past and present of hepatitis E in the Netherlands. Transfusion. 2014;54(12):3092-6.

39. Christensen PB, Engle RE, Hjort C, Homburg KM, Vach W, Georgsen J, Purcell $\mathrm{RH}$. Time trend of the prevalence of hepatitis $\mathrm{E}$ antibodies among farmers and blood donors: a potential zoonosis in Denmark. Clin Infect Dis. 2008; 47(8):1026-31.

40. Hogema BM, Molier M, Sjerps M, de Waal M, van Swieten P, van de Laar T, Molenaar-de Backer M, Zaaijer HL. Incidence and duration of hepatitis $\mathrm{E}$ virus infection in Dutch blood donors. Transfusion. 2016;56(3):722-8.

41. Juhl D, Baylis SA, Blümel J, Görg S, Hennig H. Seroprevalence and incidence of hepatitis E virus infection in German blood donors. Transfusion. 2014; 54(1):49-56.

42. Baylis SA, Gärtner T, Nick S, Ovemyr J, Blümel J. Occurrence of hepatitis E virus RNA in plasma donations from Sweden, Germany and the United States. Vox Sang. 2012;103(1):89-90

43. Horvatits T, Ozga AK, Westhölter D, Hartl J, Manthey CF, Lütgehetmann M, Rauch G, Kriston L, Lohse AW, Bendall R, Wedemeyer H, Dalton HR, Pischke S. Hepatitis E seroprevalence in the Americas: a systematic review and meta-analysis. Liver Int. 2018 Apr 16.

44. Boxall E, Herborn A, Kochethu G, Pratt G, Adams D, ljaz S, Teo CG. Transfusion-transmitted hepatitis $E$ in a 'nonhyperendemic' country. Transfus Med. 2006;16(2):79-83.

45. Westhölter D, Hiller J, Denzer U, Polywka S, Ayuk F, Rybczynski M, Horvatits T, Gundlach S, Blöcker J, Schulze Zur Wiesch J, Fischer N, Addo MM, Peine S, Göke B, Lohse AW, Lütgehetmann M, Pischke S. HEV-positive blood donations represent a relevant infection risk for immunosuppressed recipients. J Hepatol. 2018;69(1):36-42.

46. Dreier J, Knabbe C, Vollmer T. Transfusion-transmitted hepatitis E: NAT screening of blood donations and infectious dose. Front Med (Lausanne). 2018;5:5.

47. Tedder RS, ljaz S, Kitchen A, Ushiro-Lumb I, Tettmar Kl, Hewitt P, Andrews N. Hepatitis E risks: pigs or blood-that is the question. Transfusion. 2017;57(2): 267-72.

48. Satake M, Matsubayashi K, Hoshi Y, Taira R, Furui Y, Kokudo N, Akamatsu N, Yoshizumi T, Ohkohchi N, Okamoto H, Miyoshi M, Tamura A, Fuse K, Tadokoro K. Unique clinical courses of transfusion-transmitted hepatitis $E$ in patients with immunosuppression. Transfusion. 2017;57(2):280-8.

49. Schlosser B, Stein A, Neuhaus R, Pahl S, Ramez B, Krüger DH, Berg T, Hofmann J. Liver transplant from a donor with occult HEV infection induced chronic hepatitis and cirrhosis in the recipient. J Hepatol. 2012; 56(2):500-2.

50. Pischke S, Suneetha PV, Baechlein C, Barg-Hock H, Heim A, Kamar N, Schlue J, Strassburg CP, Lehner F, Raupach R, Bremer B, Magerstedt P, Cornberg M, Seehusen F, Baumgaertner W, Klempnauer J, Izopet J, Manns MP, Grummer $\mathrm{B}$, Wedemeyer $\mathrm{H}$. Hepatitis $\mathrm{E}$ virus infection as a cause of graft hepatitis in liver transplant recipients. Liver Transpl. 2010;16(1):74-82.

51. Pischke S, Greer M, Hardtke S, Bremer B, Gisa A, Lehmann P, Haverich A, Welte T, Manns MP, Wedemeyer H, Gottlieb J. Hepatitis E study group. Course and treatment of chronic hepatitis $E$ virus infection in lung transplant recipients. Transpl Infect Dis. 2014;16(2):333-9.

52. Ankcorn MJ, ljaz S, Poh J, Elsharkawy AM, Smit E, Cramb R, Ravi S, Martin K, Tedder R, Neuberger J. Toward systematic screening for persistent hepatitis E virus infections in transplant patients. Transplantation. 2018;102(7):1139-47.

53. Riveiro-Barciela M, Sauleda S, Quer J, Salvador F, Gregori J, Pirón M, Rodríguez-Frías F, Buti M. Red blood cell transfusion-transmitted acute hepatitis $E$ in an immunocompetent subject in Europe: a case report. Transfusion. 2017;57(2):244-7.

54. Riveiro-Barciela M, Bes M, Quer J, Valcarcel D, Piriz S, Gregori J, Llorens M, Salcedo MT, Piron M, Esteban R, Buti M, Sauleda S. Thrombotic thrombocytopenic purpura relapse induced by acute hepatitis $E$ transmitted by cryosupernatant plasma and successfully controlled with ribavirin. Transfusion. 2018;58(11):2501-5.

55. Grewal P, Kamili S, Motamed D. Chronic hepatitis E in an immunocompetent patient: a case report. Hepatology. 2014;59(1):347-8.

56. Dalton HR, Kamar N, van Eijk JJ, Mclean BN, Cintas P, Bendall RP, Jacobs BC. Hepatitis E virus and neurological injury. Nat Rev Neurol. 2016;12(2):77-85.

57. Cao D, Cao QM, Subramaniam S, Yugo DM, Heffron CL, Rogers AJ, Kenney SP, Tian D, Matzinger SR, Overend C, Catanzaro N, LeRoith T, Wang H, Piñeyro P, Lindstrom N, Clark-Deener S, Yuan L, Meng XJ. Pig model mimicking chronic hepatitis E virus infection in immunocompromised patients to assess immune correlates during chronicity. Proc Natl Acad Sci U S A. 2017;114(27):6914-23.

58. Saravanabalaji S, Tripathy AS, Dhoot RR, Chadha MS, Kakrani AL, Arankalle VA. Viral load, antibody titers and recombinant open reading frame 2 proteininduced $\mathrm{TH} 1 / \mathrm{TH} 2$ cytokines and cellular immune responses in self-limiting and fulminant hepatitis e. Intervirology. 2009:52(2):78-85.

59. Zhu FC, Zhang J, Zhang XF, Zhou C, Wang ZZ, Huang SJ, Wang H, Yang CL, Jiang HM, Cai JP, Wang YJ, Ai X, Hu YM, Tang Q, Yao X, Yan Q, Xian YL, Wu T, Li YM, Miao J, Ng MH, Shih JW, Xia NS. Efficacy and safety of a recombinant hepatitis $E$ vaccine in healthy adults: a large-scale, randomised, double-blind placebo-controlled, phase 3 trial. Lancet. 2010;376(9744):895-902.

60. Wu T1, Li SW, Zhang J, Ng MH, Xia NS, Zhao Q. Hepatitis E vaccine development: a 14 year odyssey. Hum Vaccin Immunother. 2012;8(6):823-7.

61. Thom K, Gilhooly P, McGowan K, Malloy K, Jarvis LM, Crossan C, Scobie L, Blatchford O, Smith-Palmer A, Donnelly MC, Davidson JS, Johannessen I, Simpson KJ, Dalton HR, Petrik J. Hepatitis E virus (HEV) in Scotland: evidence of recent increase in viral circulation in humans. Euro Surveill. 2018;23(12).

62. https://www.japantimes.co.jp/news/2018/02/01/national/world-firstwomans-death-linked-hepatitis-e-infection-blood-transfusion-japanesefacility/. Accessed 17 June 2019.

63. de Vos AS, Janssen MP, Zaaijer HL, Hogema BM. Cost-effectiveness of the screening of blood donations for hepatitis E virus in the Netherlands. Transfusion. 2017;57(2):258-66.

64. Kamp C, Blümel J, Baylis SA, Bekeredjian-Ding I, Chudy M, Heiden M, Henseler O, Keller-Stanislawski B, de Vos AS, Funk MB. Impact of hepatitis $E$ virus testing on the safety of blood components in Germany - results of a simulation study. Vox Sang. 2018;113(8):811-3.

65. Denner J. Hepatitis E virus (HEV)-the future. Viruses. 2019;13(3):11.

66. Loyrion E, Trouve-Buisson T, Pouzol P, Larrat S, Decaens T, Payenter JP. Hepatitis E virus infection after platelet transfusion in an immunocompetent trauma patient. Emerg Infect Dis. 2017;23.

67. Grewal P, Kamili S, Motamed D. Chronic hepatitis E in an immunocompetent patient: a case report. Hepatology, Hepatology. 2014; 59(1):347-8

\section{Publisher's Note}

Springer Nature remains neutral with regard to jurisdictional claims in published maps and institutional affiliations. 